\title{
Seedling length and soybean seed vigor
}

\section{Michele Renata Revers Meneguzzo ${ }^{*}$ (i) Géri Eduardo Meneghello ${ }^{2}$ (i) Ariele Paula Nadal ${ }^{2}$ (i)

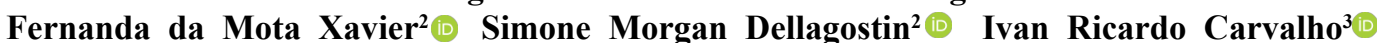

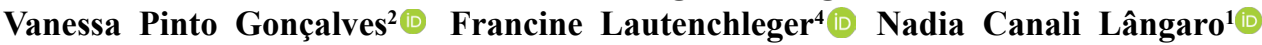

${ }^{1}$ Programa de Pós-graduação em Agronomia, Universidade de Passo Fundo (UPF), 99052-900, Passo Fundo, RS, Brasil. E-mail: michelemeneguzzo@yahoo.com.br. "Corresponding author.

${ }^{2}$ Programa de Pós-graduação em Ciência e Tecnologia de Sementes, Universidade Federal de Pelotas (UFPel), Pelotas, RS, Brasil.

${ }^{3}$ Universidade Regional do Noroeste do Estado do Rio Grande do Sul (UNIJUÍ), Ijuí, RS, Brasil.

${ }^{4}$ Universidade Estadual do Centro-Oeste (Unicentro), Guarapuava, PR, Brasil.

ABSTRACT: The differentiation of seedling growth and development is the result of the vigor level of the seed lot. Because of this, knowing the seedling growth curve is essential for the evaluation of the seedling length test, to be carried out at the moment when any differences in vigor really manifest, thus being able to reduce the time of evaluation of the test. In this research, the objective was to determine the most efficient time interval to perform the seedling length test in soybean seeds, depending on the vigor levels. The evaluated characteristics were percentage of seed germination, first germination count, emergency, days for emergence, aerial, root and total length (evaluated every 12 hours), aerial, root and total dry mass in completely randomized design. High vigor seeds originated seedlings with higher growth rates (cm. $\left.h^{-1}\right)$, with vigor being one of the factors that interfere in the seedling length test. After 96 hours of the seedling length test, there was a statistical differentiation between the three vigor levels tested. The soybean seedling length test between lots, with different vigor, can be performed 96 hours after sowing.

Key words: Glycine max, seedling growth, vigor tests.

Comprimento de plântulas e vigor de sementes de soja

RESUMO: A diferenciação do crescimento e desenvolvimento das plântulas, é resultado do nível de vigor do lote das sementes. Em virtude disto, conhecer a curva de crescimento das plântulas é fundamental para que a avaliação do teste de comprimento de plântulas, seja realizada no momento em que realmente se manifestem as eventuais diferenças de vigor, podendo assim reduzir o tempo de avaliação do teste. No trabalho, o objetivo foi determinar o intervalo de tempo mais eficiente para realizar o teste de comprimento de plântula em sementes de soja, em função dos níveis de vigor. As características avaliadas foram germinação, primeira contagem de germinação, emergência, dias para emergência, comprimento de parte aérea, raiz e total (avaliados de 12 em 12 horas), massa seca de parte aérea, raiz e total em delineamento inteiramente casualizado. As sementes de alto vigor originaram plântulas com maiores taxas de crescimento (cm. $h^{-1}$ ), sendo o vigor um dos fatores que interfere no teste de comprimento de plântulas. Após 96 horas do teste de comprimento de plântula ocorreu a diferenciação estatística entre os três niveis de vigor testados. O teste de comprimento de plântula de soja entre lotes, com vigor distinto, pode ser realizado 96 horas após a semeadura.

Palavras-chave: Glycine max, crescimento de plântula, testes de vigor.

\section{INTRODUCTION}

The use of high value-added seeds with genetic, physical, physiological and sanitary quality plays a fundamental role in obtaining the full productive potential of the species. High quality seeds involve a number of characteristics, among which are the physiological attributes, which are vigor and germination (MARCOS FILHO, 2002).

Vigor tests are an increasingly routine tool used by seed industries to determine their physiological quality (MARCOS FILHO, 1999). The vigor tests based on the performance of the seedlings can be classified as physiological tests (MCDONALD 
JR., 1975), whose manifestation is dependent on vigor (VANZOLINI et al., 2007), making it possible to list lots with different levels of vigor (MARCOS FILHO et al., 2009).

The analysis of growth stands out as a precise, fast and accessible method relatively simple, cost-effective, do not require special equipment or deep training (ALVARENGA et al., 2013). It allows the study of the seedling performance under different environmental conditions and under management practice, and it is possible to evaluate the contribution of different physiological processes on plant performance (RADFORD, 1967; LOPES \& LIMA, 2015). It can be used to investigate the effect of ecological phenomena on plant growth, as well as seed quality on initial soybean growth (AISENBERG et al., 2014) and beans (FACIN et al., 2014).

The evaluation of the physiological potential of seeds in laboratories is important for seed companies, in order to reduce risks and costs, always aiming quality control and the adoption of commercial strategies (BARBIERI et al., 2012). However, for research purposes, the performance of additional evaluations, characterize the initial growth of plants in the laboratory and in the field, is an important tool to assess the inference of the vigor and size of the seeds, on the expression of their physiological potential in field conditions.

For this, several tests are carried out to evaluate the vigor of seeds, among them the determination of the average length of normal seedlings or parts of them (NAKAGAWA, 1999). However, their growth and development is different depending on the vigor level of the batch. Knowing the seedling growth curve due to these differences is essential for the assessment to be carried out at a time when any differences in vigor really manifest.

The seedling length test or its parts have been considered efficient to detect differences in the physiological potential of seeds of several species (NAKAGAWA, 1999). At the same time, in addition to this sensitivity, its results may have a close relationship with the emergence of seedlings in the field (KRZYZANOWSKI, 1991; VANZOLINI et al., 2007). Given the above, the objective of this research is to determine the best time to perform the seedling length test on soybean seeds, depending on the vigor levels.

\section{MATERIALS AND METHODS}

Soybean seeds of cultivar 5855 RSF IPRO (BMX ELITE), stratified by the accelerated aging method into three sub-lots, denominated high, medium and low vigor were used. To characterize the initial quality of the seeds, for each level of vigor and seed size, several evaluations were conducted, as follows:

Germination test: conducted with eight subsamples of 100 seeds, having as substrate three sheets of germitest trademark Germilab paper, moistened with distilled water in an amount equivalent to 2,5 times the mass of the dry paper. Seeds were kept in a germination chamber with a temperature of 25 ${ }^{\circ} \mathrm{C}$. The seedlings considered normal were evaluated in a period of eight days after sowing, according to the recommendations of the Rules for Seed Analysis (RAS) (BRASIL, 2009).

First germination count: it was performed along with the germination test, computing the percentage of normal seedlings present on the fifth day after the test installation.

Emergence: 400 seeds were used, divided into eight replicates of 50 seeds, sown in the Planosol soil (Alfisol), at a depth of $3 \mathrm{~cm}$. Emerging seedling counts were performed 21 days after sowing, and results were expressed as percentage of emerged plants.

Days for emergence: then the test was conducted along with the emergence test in bed by daily counts always at the same time until a constant number of seedlings emerged. To calculate the emergency speed, the formula described by Edmond and Drapala (1958) was used. Together, the emergency speed index, suggested by Maguire (1962), was calculated.

Root, shoot and total seedling length test: four replicates of 20 seeds were used, which were placed to germinate under the same germination test conditions. The seeds were distributed in the longitudinal direction of the germitest paper with the micropyle facing the bottom of the paper. The rolls were packed in plastic bags and placed vertically in the regulated germinator at $25^{\circ} \mathrm{C}$. For the evaluation, 4 replicates of 10 seedlings for each treatment, randomly chosen, were evaluated, from 36 hours after sowing, with a 12 - hour interval of 12 hours. The evaluation of the seedling length was performed with the help of a ruler graduated in centimeters. The evaluations were carried out up to 204 hours after sowing. Each seedling was individualized in the evaluation, in order to observe the effective growth curve. The mean results were expressed in centimeters per seedlings, for each treatment.

Dry matter of the seedlings: after the evaluation of the length of the shoot and root, the seedlings of each replication, after the cotyledons were removed, were separated in shoot and root and 
then they were kept in the oven at $65^{\circ} \mathrm{C}$, for 72 hours. After, the weighing of the ten seedlings was carried out in an analytical balance of $0.001 \mathrm{~g}$ precision, and the average results were expressed in milligrams per seedlings. For the total dry mass, the sum of the shoot and root dry mass factors was performed.

During all seedling length evaluations care should be taken with temperature control per experimental unit, considering a local control (blocks), due to the precision of the test.

It was used a completely randomized design; however, for the variables germination, first germination count, emergence, days for emergence and dry mass of the seedlings, the arrangement was unifatorial with three levels of vigor for the seeds with eight repetitions. For plant length due to the factor time the arrangement became $3 \times 15$, corresponding to vigor levels $\mathrm{x}$ times of evaluations, both with four replications.

\section{Statistical analyses}

The data obtained were subjected to the assumptions of the statistical model, tested whether the homogeneity and normality of the residual variances, as well as the additivity of the model $\left(\mathrm{y}_{\mathrm{jik}}\right.$ $\left.=\mathrm{m}+\mathrm{b}_{\mathrm{j}}+\mathrm{A}_{\mathrm{i}}+\mathrm{B}_{\mathrm{k}}+(\mathrm{AB})_{\mathrm{ik}}+\mathrm{e}_{\mathrm{jik}}\right)$, being: $\mathrm{y}_{\mathrm{jik}}$ : value observed in the $\mathrm{j}$-th experimental unit, belonging to the $\mathrm{i}$-th vigor level and $\mathrm{k}$-th evaluation time, $\mathrm{bj}$ : refers to $\mathrm{j}$-th repetition for the treatments tested, Ai: the effect of the $\mathrm{i}$-th level of vigor is evident, Bk: expresses the $\mathrm{k}$-th evaluation time, $\mathrm{e}_{\mathrm{jik}}$ experimental error associated with yjik based on that ejik $\sim \mathrm{N}(0$, $\sigma^{2}$ ) and independent. After the analysis of variance was performed in order to identify the interaction between vigor levels and test evaluation times, at 5\% probability, both variation factors were assumed to be fixed due to the nature of the study and previous planning the significant interactions.

They were subject to the simple effects at $5 \%$ probability matrix by tukey. $\mathrm{O}$ fator quantitative (tempos de avaliação) foi submetido ao modelo $\mathrm{y}_{\mathrm{jik}}=$ $\mathrm{b}_{0}+\mathrm{b}_{1} \mathrm{x}_{\mathrm{k}}+\mathrm{b}_{2} \mathrm{x}_{\mathrm{k}}{ }_{\mathrm{k}}+\ldots+\mathrm{b}_{\mathrm{n}} \mathrm{x}_{\mathrm{k}}^{\mathrm{n}}+\mathrm{e}_{\mathrm{i},}$ being $\mathrm{y}_{\mathrm{jik}}$ : observed value, $b_{0}$ angular coefficient of origin, $b_{1} x_{k}$ : slope representing the linear degree, $\mathrm{b}_{2} \mathrm{x}_{\mathrm{k}}{ }_{\mathrm{k}}, \mathrm{b}_{\mathrm{n}} \mathrm{x}_{\mathrm{k}}^{\mathrm{n}}$ : slope with a higher degree of the polynomial, $\mathrm{e}_{\mathrm{i}}$ : associated experimental error, these models being tested at $5 \%$ probability by the $t$ test for each level of the qualitative factor.

\section{RESULTS}

The summary of the variance analysis of the results indicated a significant effect on vigor levels for the first germination count (FGC), percentage of seed germination $(\mathrm{G})$, emergency speed index (ESI), days for emergence (DE), emergence (E), shoot dry mass (SDM) and total dry mass (TDM) (Table 1).

There was a significant interaction between levels of vigor and time of the evaluations for the variables shoot length (SL), root length (RL) and total length (TL), evidencing different behavior of variables as a function of factors (Table 2).

Seeds of high vigor presented higher physiological potential, not differing from seeds of medium vigor for the variables percentage of seed germination, emergence speed index, emergence, shoot dry mass and total dry mass (Table 3). Seeds with high or medium vigor (\%) when identified by the first germination and emergence count test, can influence the seed emergence speed.

The differences between the lengths of seedlings with different levels of vigor, evaluated every 12 hours, can be seen in figure 1 . From the 96 hours of evaluation, it is possible to see a significant difference for the curves of the high, medium and high levels. low vigor for the three variables evaluated. For the length of the aerial part (Figure 1A), all treatments were adjusted to the quadratic model. Seeds from high vigor lots had a longer shoot length at all times of evaluation.

The root length behavior (Figure 1B) was similar to that of shoot length. The behavior of the curves for the regressions of the treatments of high and medium vigor level was adjusted to the quadratic model and for the low level of vigor no mathematical model fitted.

In relation to the influence of vigor level on seedling growth for total seedling length (Figure 1C), the high vigor seeds showed a quadratic behavior while for the medium and low vigor level the behavior of the curve was linear.

High-vigor seeds show larger initial shoot size and continuous growth over time (Figure 2A). After 168 hours seeds of medium vigor present a growth rate higher than the high vigor level. Lowvigor seeds have an average growth rate of $0.39 \mathrm{~mm}$. $\mathrm{h}^{-1}$, lower than high-vigor seeds, throughout the evaluation period.

By analyzing seedling growth in $\mathrm{mm} \mathrm{h}^{-1}$, at intervals of 12 hours, high-vigor seeds tend to express their initial growth better due to their rapid metabolic activation and degradation of reserves. When the reserve present in the cotyledons comes to an end, the onset of growth reduction $\left(\mathrm{mm} \mathrm{h}^{-1}\right)$ occurs, this can also be explained by the lack of external nutritional support. 
Table 1 - Analysis of variance summary for the first germination count (FGC), percentage of seed germination (G), emergency speed index (ESI), days for emergence (DE), emergence (E), shoot dry mass (SDM), root dry mass (RDM) and total dry mass (TDM) depending on vigor levels.

\begin{tabular}{|c|c|c|c|c|c|c|c|c|c|}
\hline \multirow[t]{2}{*}{ Variation Factor } & \multirow[t]{2}{*}{$\mathrm{DF}$} & \multicolumn{8}{|c|}{ 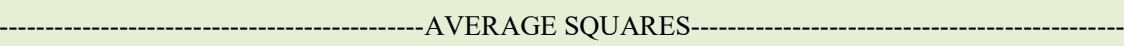 } \\
\hline & & FGC & G & ESI & $\mathrm{DE}$ & $\mathrm{E}$ & SDM & RDM & TDM \\
\hline Vigor Levels & 2 & $452.08^{*}$ & $104.08^{*}$ & $0.46^{*}$ & $0.62^{*}$ & $157.58^{*}$ & $71.30^{*}$ & 1.70 & $73.91^{*}$ \\
\hline Block & 7 & 1.19 & 1.41 & 0.06 & 0.33 & 11.55 & 6.24 & 0.44 & 5.76 \\
\hline Residue & 14 & 8.86 & 9.75 & 0.02 & 0.00 & 16.47 & 8.57 & 1.21 & 11.61 \\
\hline CV (\%) & & 3.64 & 3.37 & 4.99 & 0.86 & 4.54 & 10.34 & 8.54 & 8.27 \\
\hline SD & & 9.34 & 4.96 & 0.33 & 0.45 & 6.39 & 4.39 & 1.04 & 4.64 \\
\hline
\end{tabular}

${ }^{*}$ significant at $5 \%$ probability by the $\mathrm{F}$ test.

DF - Degrees of freedom.

$\mathrm{SD}$ - Standard deviation.

Plants from low vigor seeds take more time to reach the peak of growth, due to their reduced capacity to use the reserves present in the cotyledons, having their growth rate reduced over time. In this way, its initial growth is slower, taking more time to establish a plant. In addition, the seed will be exposed for longer the influence of abiotic and biotic factors of the environment.

Reduction of the root growth rate occurred with the passage of evaluation times in high-vigor seeds (Figure 2B). After 132 hours the root vigor of seeds of medium vigor was superior to that of seeds of high vigor. As the regression curve for low vigor seeds was not significant for any mathematical model, it was not possible to infer the results for the root growth rate of these seeds.
Seedlings originating from medium and low vigor seeds showed linear behavior for the total length of the seedlings, with a growth rate of $1.94 \mathrm{~mm} \mathrm{h-1}$ and $1.14 \mathrm{~mm}$ h-1, respectively (C). While high vigor seeds showed an initial total growth rate, superior to seeds of medium and low vigor, but after the interval of 132 to 144 hours of evaluations, seeds of medium vigor presented a higher rate. Higher initial velocity is an advantage of more vigorous seeds than those with lower vigor.

\section{DISCUSSION}

The effectiveness of vigor tests depends on the proper choice of method, depending on the intended objectives, so the use of only one test can

Table 2 - Analysis of variance summary for the variables shoot length (SL), root length (RL) and total length (TL) of seedlings related to the vigor levels and timing of the evaluations.

\begin{tabular}{|c|c|c|c|c|}
\hline \multirow[t]{2}{*}{ Variation Factor } & \multirow[t]{2}{*}{$\mathrm{DF}$} & \multicolumn{3}{|c|}{ - } \\
\hline & & SL & RL & TL \\
\hline Vigor Levels (V) & 2 & $136.82^{*}$ & $774.33^{*}$ & $1558.52^{*}$ \\
\hline Evaluation times $(\mathrm{T})$ & 14 & $241.31^{*}$ & $280.61^{*}$ & $1031.17^{*}$ \\
\hline $\mathrm{T} \times \mathrm{V}$ & 28 & $5.45^{*}$ & $11.66^{*}$ & $31.69^{*}$ \\
\hline Block & 3 & 19.23 & 4.18 & 35.51 \\
\hline Residue & 132 & 0.49 & 2.05 & 3.34 \\
\hline $\mathrm{CV}(\%)$ & & 12.00 & 16.22 & 12.43 \\
\hline SD & & 4.68 & 5.83 & 10.29 \\
\hline
\end{tabular}

*significant at $5 \%$ probability by the $\mathrm{F}$ test.

DF - Degrees of freedom.

$\mathrm{SD}$ - Standard deviation. 
Table 3 - Comparison of means for the first germination count (FGC), percentage of seed germination (G), emergency speed index (ESI), days for emergence (DE), emergence (E), shoot dry mass (SDM) and total dry mass (TDM) according to the three levels of vigor.

\begin{tabular}{lccccccc}
\hline Vigor Levels & FGC (\%) & G $(\%)$ & ESI (days) & DE (days) & E (\%) & SDM (mg pl $\left.{ }^{-1}\right)$ & ${\text { TDM }\left(\mathrm{mg} \mathrm{pl}^{-1}\right)}$ \\
\hline High & $92 \mathrm{a}$ & $98 \mathrm{a}$ & $3.18 \mathrm{a}$ & $7.71 \mathrm{c}$ & $95 \mathrm{a}$ & $31.94 \mathrm{a}$ & $45.36 \mathrm{a}$ \\
Medium & $82 \mathrm{~b}$ & $91 \mathrm{ab}$ & $2.89 \mathrm{a}$ & $8.06 \mathrm{~b}$ & $90 \mathrm{ab}$ & $29.26 \mathrm{ab}$ & $41.43 \mathrm{ab}$ \\
Low & $71 \mathrm{c}$ & $88 \mathrm{~b}$ & $2.51 \mathrm{~b}$ & $8.49 \mathrm{a}$ & $86 \mathrm{~b}$ & $23.66 \mathrm{~b}$ & $36.77 \mathrm{~b}$ \\
CV $(\%)$ & 3.64 & 3.37 & 4.99 & 0.86 & 4.54 & 10.34 \\
\hline
\end{tabular}

${ }^{1}$ Means followed by the same letter, minus case in the column, do not differ by Tukey test $(\mathrm{p}<0.05)$.

generate incomplete information. As a consequence, the initial evaluation, as well as the initial length and development of the seedlings, maintained the trend regarding the vigor manifestation, in which seeds of greater vigor presented higher physiological potential for the tests performed. Thus, the methodology for the evaluation of seedling length is an efficient, fast and feasible method to evaluate seed vigor.

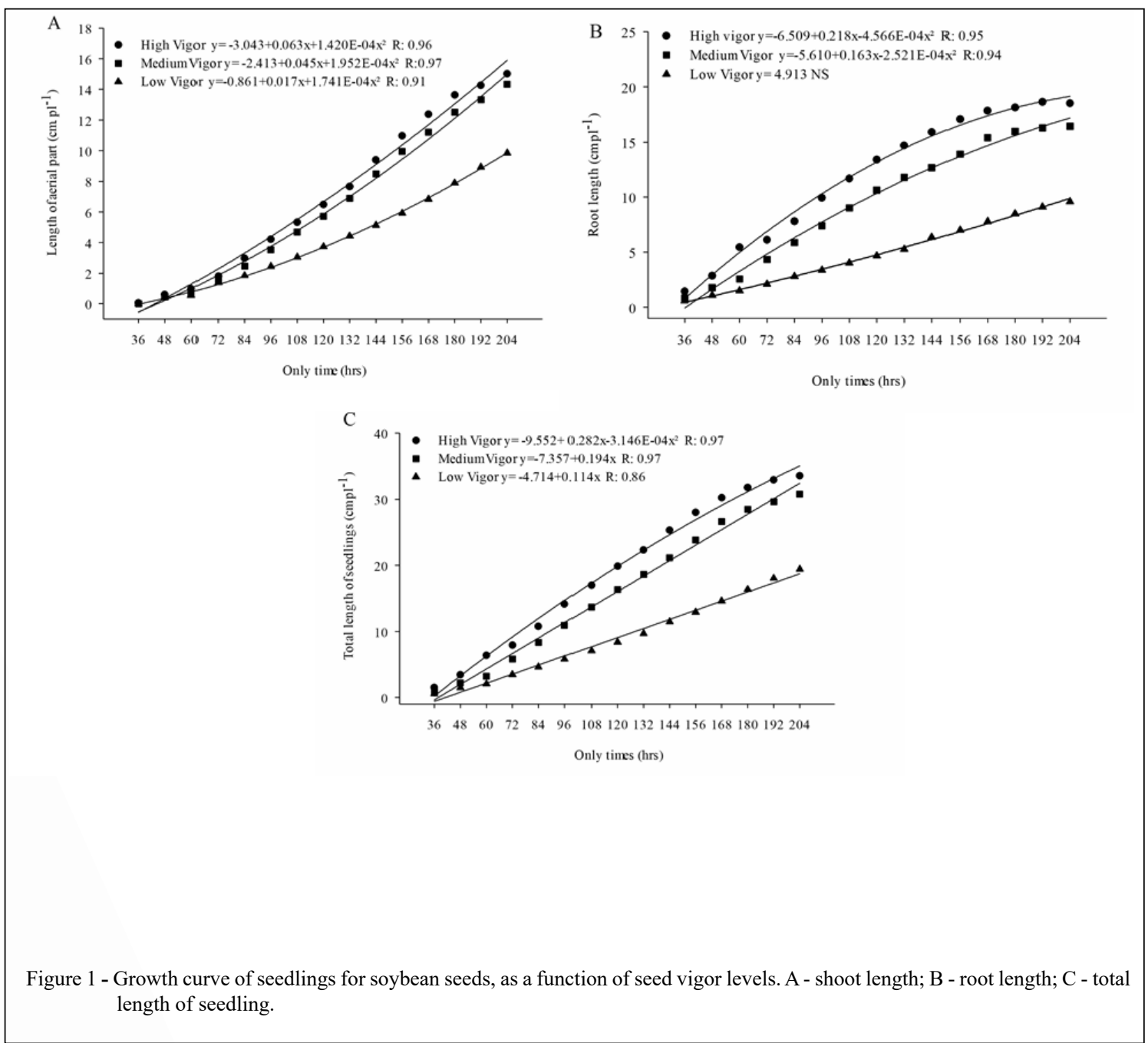

Ciência Rural, v.51, n.7, 2021. 


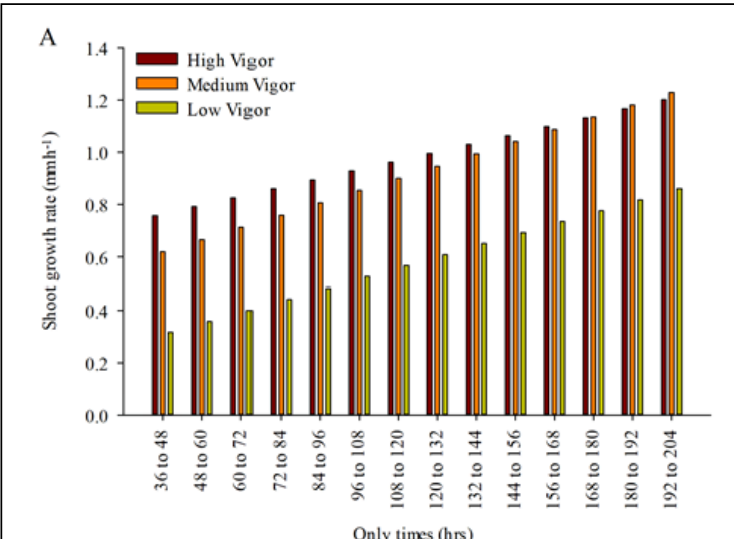

Only times (hrs)
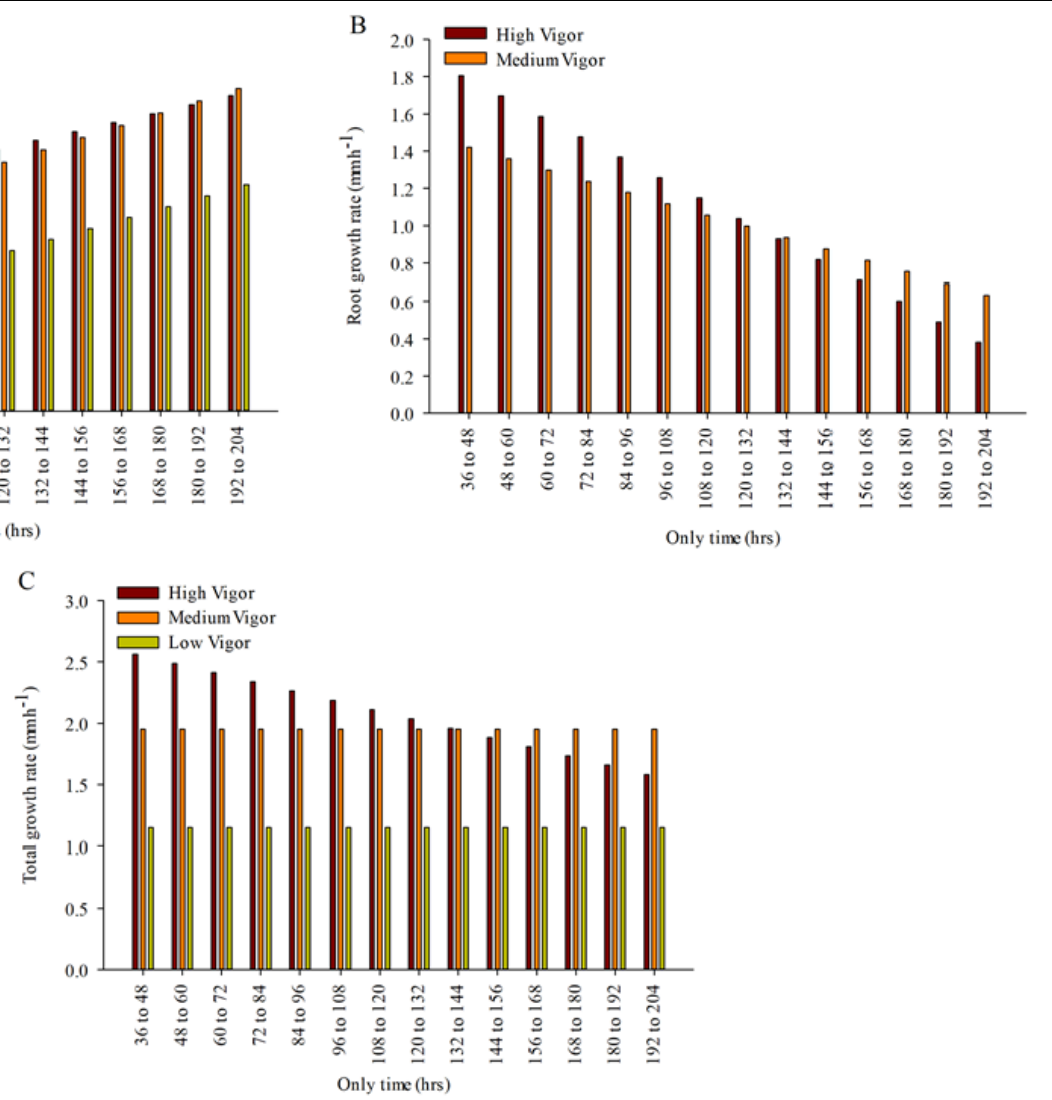

Figure 2 - Growth rate of soybean seedlings, due to seed vigor level. A - Shoot growth rate; B - Root growth rate; C - Total growth rate.

The development of these tests of length and initial development of seedlings for other species may be a consistent alternative to obtain reliable results, since the procedures are relatively simple, fast and economical and can be reproduced and standardized for other species.

According to FESSEL et al. (2010) and MARCOS FILHO (2013), the main objective of seed technology has been the use of efficient procedures for the production, commercialization and use of high-quality seed lots. This knowledge allows reliable and reproducible results to be obtained to detect and solve problems during the production process.

Vigorous seeds give rise to seedlings with higher growth rate, due to the greater capacity of transformation and supply of reserves of the storage tissues and the greater incorporation of these by the embryonic axis (DAN et al., 1987). Fields cultivated with high vigor soybean seeds; consequently, presented better productive indexes (KOLCHINSKI et al., 2005).

The reduction in the physiological quality of the seeds of white oats, caused reductions and caused unevenness of the emergence in the field. VANZOLINI \& CARVALHO (2002) verified that the most vigorous soybean seeds produced seedlings with a longer primary and total root length of seedlings. Other authors report that root length is more sensitive for differentiating soybean lots (KRZYZANOWSKI, 1991; NAKAGAWA, 1999; VANZOLINI; 2002).

The early protrusion of the primary root is related to the period and amount of energy consumed to reactivate the metabolism and activity of membrane repair mechanisms and resumption of DNA and protein synthesis. This period and energy consumption are shorter in more deteriorated or less vigorous seeds, expressing the delay in germination and the slower growth rate (MATHEWS et al., 2007, 2010). 
The guarantee of a good production is the use of seeds of high vigor, being fundamental to maximize the production, because it guarantees greater speed and percentage of germination, influencing the stand and the spatial arrangement of the crops. However, the late emergence of seedlings, reflecting the less vigor of seeds, can lead to low survival at maturity (ELLIS, 1992; MARCOS FILHO, 2015).

\section{CONCLUSION}

The best time to perform the seedling length test on soybean seeds is 96 hours after sowing, where it will be possible to distinguish the vigor lots of these seeds.

\section{ACKNOWLEDGMENTS}

The present work was carried out with the support of the Coordenação de Aperfeiçoamento de Pessoal de Nível Superior (CAPES) - Financing Code 001.

\section{DECLARATION OF CONFLICT OF INTEREST}

The authors declare no conflict of interest. The founding sponsors had no role in the design of the study; in the collection, analyses, or interpretation of data; in the writing of the manuscript, and in the decision to publish the results.

\section{AUTHORS' CONTRIBUTIONS}

All authors contributed equally for the conception and writing of the manuscript. All authors critically revised the manuscript and approved of the final version.

\section{REFERENCES}

AISENBERG, G. R.; et al. Vigor and initial growth performance of soybean plants: effect of sowing depth. Enciclopédia Biosfera, v.10, n.18, p.3081-3091, 2014. Available from: <http://www. conhecer.org.br/enciclop/2014a/AGRARIAS/VIGOR\%20E\%20 DESEMPENHO.pdf>. Accessed: Mar. 15, 2019.

ALVARENGA, R. O.; MARCOS-FILHO, J.; TIMÓTEO, T. S. Assessment of the physiological potential of super sweet corn seeds. Journal of Seed Science, v.35, n.3, p.340-346, 2013. Available from: <http://dx.doi.org/10.1590/S231715372013000300010>. Accessed: Apr. 10, 2019. doi: 10.1590/ S2317-15372013000300010.

ASSOCIATION OF OFFICIAL SEED ANALYSTS. Seed vigor testing handbook. East Lansing: AOSA, 1983. 93p. (Contribution 32).

BARBIERI, A. P. P.; MENEZES, N. L.; CONCEIÇÃO, G. M.; TUNES, L. M. de. Potassium leaching test to assess the vigor of rice seeds. Revista Brasileira de Sementes, v.34, n.1, p.117 - 124, 2012. Available from: <http://dx.doi.org/10.1590/S0101-
31222012000100015>. Accessed: May, 3, 2019. doi: 10.1590/ S0101-31222012000100015.

BRASIL. Ministério da Agricultura, Pecuária e Abastecimento. Regras para análise de sementes. Ministério da Agricultura, Pecuária e Abastecimento. Secretaria de Defesa Agropecuária. Brasília: MAPA/ACS, 399p. 2009. Online. Available from: <http:// www.bs.cca.ufsc.br/publicacoes/regras $\% 20$ analise $\% 20$ sementes. pdf $>$. Accessed: Nov. 15, 2018.

DAN, E. L. et al. Dry matter transfer as a method of assessing soybean seed vigor. Revista Brasileira de Sementes, v.9, n.3, p.45-55. 1987.

ELLIS, R. H. Seed and seedling vigor in relation to crop growth and yield. Plant Growth Regulation, v.11, p.249-255, 1992. Available from: <https://doi.org/10.1007/BF00024563>. Accessed: May, 7, 2019. doi: 10.1007/BF00024563.

FACIN, F.; et al. Seed vigor and initial growth of bean plants under low temperatures. Tecnologia \& Ciência Agropecuária, v.8, n.4, p.35-40, 2014. Available from: <http://revistatca.pb.gov. br/edicoes/volume-08-2014/volume-8-numero-4-outubro-2014/ tca8407.pdf $>$. Accessed: May, 17, 2019.

FESSEL, S. A. et al. Electrical conductivity test on soybean seeds stored under different temperatures. Bragantia, v.69, n.1, p.207214, 2010. Available from: <http://dx.doi.org/10.1590/S000687052010000100026>. Accessed: Apr. 20, 2019. doi: 10.1590/ S0006-87052010000100026.

KOLCHINSKI, E. M. et al. Seed vigor and intraspecific competition in soybeans. Ciência Rural, v.35, n.6, p.12481256, 2005. Available from: <http://dx.doi.org/10.1590/S010384782005000600004>. Accessed: Apr. 20, 2019. doi: 10.1590/ S0103-84782005000600004.

KRZYZANOWSKI, F. C. Soybean seedling root length test. Informativo ABRATES, Brasília, v.2, n.1, p.11-14, 1991.

LOPES, N. F.; LIMA, M. G. S. Iinterception and distribution of radiant energy in terrestrial communities. In: LOPES, N.F.; LIMA, M.G. S. Fisiologia da produção. Viçosa, MG: Ed. UFV, 117144p., 2015.

MARCOS FILHO, J. Importância do potencial fisiológico da semente de soja. Informativo ABRATES, v.23, n.1, p.2124, 2013. Available from: <https://www.abrates.org.br/img/ informations/950ff7fa-c03a-4960-a520-f6cb0870babe IA $\% 20$ vol.23\%20n.1.pdf>. Accessed: Apr. 20, 2019.

MARCOS FILHO, J. Fisiologia de sementes de plantas cultivadas. 2.ed. Londrina: ABRATES, 2015. 659p.

MARCOS FILHO, J.; KIKUTI, A. L. P.; DE LIMA, L. B. Methods for assessing soybean seed vigor, including computerized image analysis. Revista Brasileira de Sementes, v.31, n.1, p.102-112, 2009.

MARCOS FILHO, J. Testando o vigor de sementes. Seed News, Pelotas, n.2, p.12-13, 2002.

MARCOS FILHO, J. Testes de vigor: Importância e Utilização. In: KRZYZANOWSKI, F. C.; VIEIRA, R. D.; FRANÇA-NETO, J. B. Vigor de sementes: conceitos e testes. Londrina: ABRATES, 1999. cap.3, p.1-24 
McDONALD JR, M. B. A review and evaluation of seed vigor tests. Proceedings of the International Seed Testing Association, v.65, n.1, p.109-139, 1975.

NAKAGAWA, J. Testes de vigor baseados no desempenho das plântulas. In: KRZYZANOWSKI, F.C.; VIEIRA, R.D.; FRANÇA NETO, J.B. (Ed.). Vigor de sementes: conceitos e testes. Londrina: ABRATES, p.2.1-2.24, 1999.

RADFORD, P. J. Growth analysis formulae: their use and abuse. Crop Sciece, v.7, n.3, p.171-175, 1967. Accessed: May, 07, 2019. doi: 10.2135/cropsci1967.0011183X000700030001x.
VANZOLINI, S.; ARAKI, C. A. S.; SILVA, A. C. M. T.; NAKAGAWA, J. Seedling length test in assessing the physiological quality of soybean seeds. Revista Brasileira de Sementes, v.29, n.2, p.90-96, 2007. Available from: <http://dx.doi.org/10.1590/ S0101-31222007000200012>. Accessed: May, 07, 2019. doi: 10.1590/S0101-31222007000200012.

VANZOLINI, S.; CARVALHO, N. M. Effect of soybean seed vigor on field performance. Revista Brasileira de Sementes, v.24, n.1, p.33-41, 2002. Available from: $<$ http://dx.doi.org/10.1590/S010131222002000100006>. Accessed: Jun. 5, 2019. doi: 10.1590/ S0101-31222002000100006. 